of staphylococci became common in outpatient departments the results of treatment with penicillin might be different.

We gratefully acknowledge the help of Mr. James O. Robinson, surgeon in charge of outpatients; the sisters and nursing staff of the casualty department ; Miss Y. E, Fillis, pharmacist, and Miss E. J. Armour, statistician, St. Bartholomew's Hospital, and Mr. G. Eastman, computer programmer, Birmingham Hospital Regional Board.
REFERENCES

Burn, J. I., Curwen, M. P., Huntsman, R. G., and Shooter, R. A. (1957). Brit. med. F., 2, 193.

Geddes, A. M., Sleet, R. A., and Murdoch, J. McC. (1964). Brit. med. 7., 2, 670 .

Harnecker, J.; Contreras, J., Gilabert, B., and Ubilla, V. (1963). Antimicrobial Agents and Chemotherapy, 204

McCall, C. E., Steigbigel, N. H., and Finland, M. (1967). Amer. 7. med. Sci., 254, 144 .

MacFarlane, D. A., Murrell, J. S., Shooter, R. A., and Curwen, M. P. (1960). Brit. med. \%., 2, 900 .

Richmond, M. H., Parker, M. T., Jevons, M. P., and John, M. (1964). Lancet, 1, 293.

\title{
X-linked Recessive Inheritance in the Ehlers-Danlos Syndrome*
}

\author{
P. BEIGHTON, $\dagger$ M.R.C.P., M.R.C.P.ED., D.C.H., D.T.M.\&H.
}

Brit. med. F., 1968, 3. 409-411

\begin{abstract}
Cummary: Two families are described in which the Ehlers-Danlos syndrome is apparently transmitted as an $\mathrm{X}$-linked recessive character. The results of tests for the $\mathrm{Xg}$ blood groups and for colour vision show that the locus for the Ehlers-Danlos syndrome is not close to that for the $\mathrm{Xg}$ groups nor very close to the locus for deutan colour-blindness.
\end{abstract}

The clinical features of this variety of the EhlersDanlos syndrome include considerable hyperextensibility of the skin and a bruising tendency.

\section{Introduction}

The Ehlers-Danlos syndrome is an uncommon genetically determined disorder of connective tissue which is usually inherited as an autosomal dominant character (McKusick, 1966a). The major features of the condition are joint hypermobility, skin hyperextensibility, and a tendency for the skin to split on minor trauma with the formation of thin, gaping scars. Other variable concomitants are a liability to frequent bruising and musculoskeletal, cardiovascular, and ocular abnormalities.

* This paper represents part of a thesis submitted for the M.D. of the University of London.

t Medical Registrar, St. Thomas's Hospital, London S.E.1. Present address: Dept. of Genetics, Johns Hopkins Hospital, Baltimore, U.S.A.

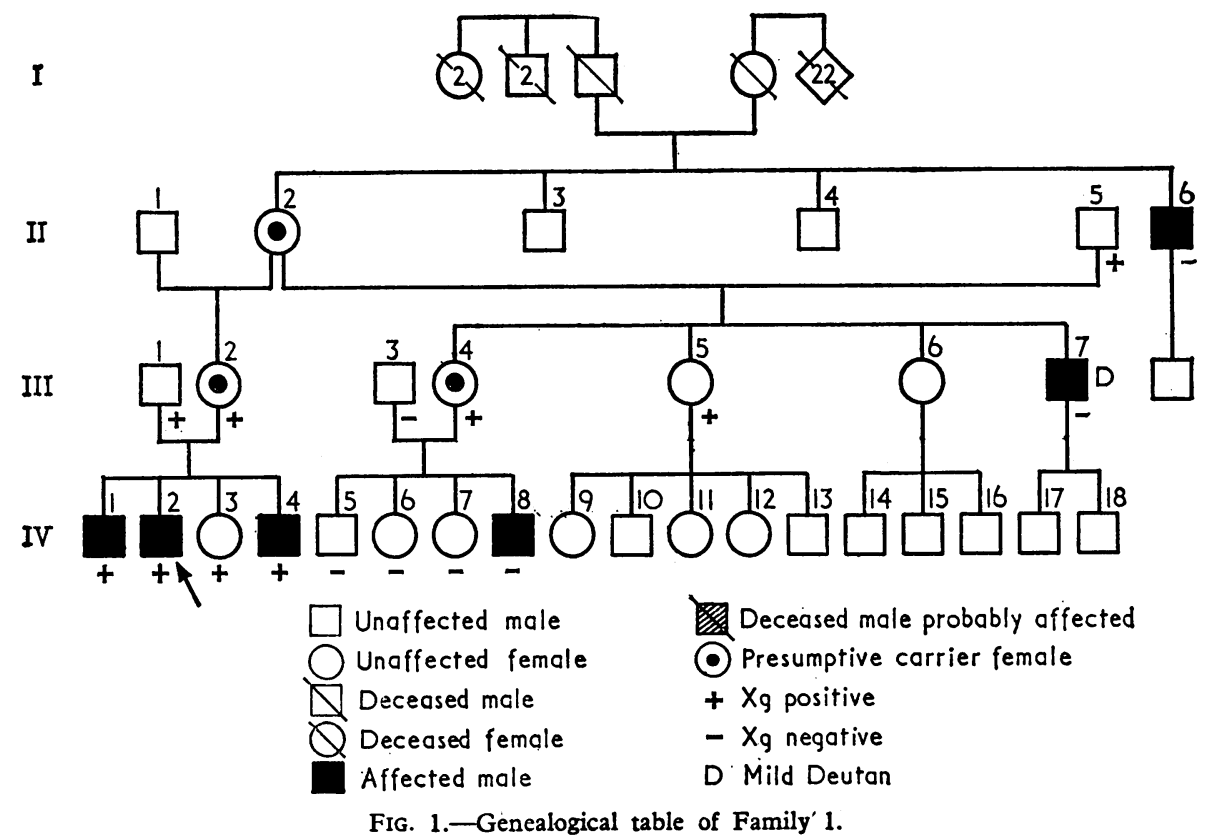

\section{Present Investigation}

During a survey in Southern England 100 patients with Ehlers-Danlos syndrome were fully examined. Twenty-nine of them had no affected relatives and were apparently sporadic cases. The other 71 were members of 22 separate families, and with the exception of the two described in this paper the condition was transmitted by the typical autosomal dominant mode of inheritance. In the family shown in Fig. 1 there are six affected males, and the pattern of inheritance is typical of an X-linked recessive condition. This mode of transmission was not mentioned by McKusick (1964) in his list of X-linked conditions, and it has apparently not been previously described in Ehlers-Danlos syndrome. All members of the family were examined with the exception of generation $I$ and the two males II 3 and II 4. However, the other members were adamant that neither of these brothers had any abnormality of the skin or joints.

In a second family in the series (Fig. 2) it was also possible that an $\mathrm{X}$-linked recessive mechanism of inheritance was operating. The only members of the family available for examination were the two affected brothers, III 1 and III 2 , their mother, II 5, and the children, IV 1 and IV 2. However, it was discovered from other sources that I 3 and I 4 had been well known for the loose joints in their hands and their remarkable facility for stretching their skin.

Once again the mode of transmission of the condition in this family is suggestive of the $\mathrm{X}$-linked recessive type inheritance, with the typical absence of male-to-male transmission.

In the series as a whole three other apparently sporadic males had phenotype features that corresponded to the $\mathrm{X}$-linked variety of the Ehlers-Danlos syndrome. However, in the absence of any positive family history it was impossible to make any definite assertion regarding their status. This must await the development of a biochemical method for recognition of this entity.

\section{Inheritance}

In these families there was no maleto-male transmission of the EhlersDanlos syndrome, while a total of four affected males had five unaffected sons. 
Presumptive carrier females passed the conditions to their sons and carrier status to their daughters in the ratio that would be expected in an X-linked condition.

It is possible that the condition in these families was really inherited as an autosomal dominant character which was incomplete in its penetrance, with the supposedly carrier females being formes frustes, lacking clinically detectable expression of

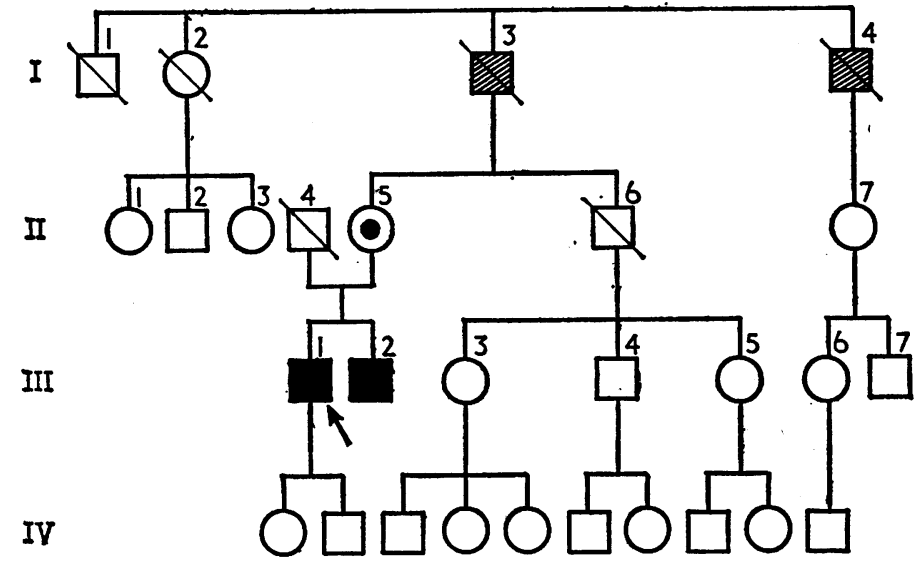

Fig. 2.-Genealogical table of Family 2. (Key as in Fig. 1.)

the gene. However, this was never the situation in any of the other families encountered during the investigation. There was pronounced similarity between affected members of the same family and marked variation in the stigmata of the condition between unrelated families, while formes frustes with absent or minimal clinical expression were not encountered. Skipped generations due to incomplete expression of the gene in an affected family did not occur.

On the evidence available it appears that these families manifest X-linked recessive inheritance of the Ehlers-Danlos syndrome. This means that although the phenotype is similar to the true Ehlers-Danlos syndrome the genotype is dissimilar, and the condition described must be a separate entity.

\section{Clinical Features}

It has already been suggested that the Ehlers-Danlos syndrome might be heterogeneous (McKusick, 1966b), and delineation into three subgroups on clinical grounds has been made by Barabas (1967). The clinical features of the patients are shown in the Table.

Skin.-All the eight affected males showed marked hyperextensibility of the skin, which on release sprang back immediately into its normal position in the manner characteristic of the Ehlers-Danlos syndrome (Fig. 3). The liability of the skin to split on minor trauma, considered by Ronchese (1936) to be the main characteristic of the Ehlers-Danlos syndrome, was present only to a minor degree in Cases $1,2,3,6$, and 7, and was virtually absent in the other patients. However, skin biopsy of Case 1 was reported as showing changes typical of the Ehlers-Danlos syndrome. Typical molluscoid pseudotumours were present in Cases $1,2,4,7$, and 8 , and the histological changes in one of these which was excised from the knee of Case 2 were characteristic of the Ehlers-Danlos syndrome. It is perhaps significant that the surgeon performing this excision remarked that after he had removed an ellipse of skin $3 \mathrm{~cm}$. in its shortest diameter from over the patella he found that closure of the wound was made difficult by the amount of redundant skin that was present. In true Ehlers-Danlos syndrome fashion this wound gaped but did not bleed. Calcified subcutaneous spheroids are often found in the EhlersDanlos syndrome They feel like hard, mobile grains of rice beneath the skin, and may be demonstrated radiologically. However, they were noted only in Cases 7 and 8 of this series.

Foints.-Joint hypermobility was present in five of the patients, and, though this feature was of marked degree, it was limited to the digits (Fig. 4). The more grossly affected cases of the Ehlers-Danlos syndrome show marked generalized joint hypermobility, but hypermobility of limited distribution of the type seen in these patients is not uncommon. It is noteworthy that recurrent joint effusions and dislocations had occurred in several of the patients in these two families. This probably indicates ligamentous involvement of a wider distribution than that suggested by the degree of joint hypermobility.

Other Concomitants.-A liability to bruising is often found in the Ehlers-Danlos syndrome. This was noted in most of the affected males in these two families. Musculoskeletal disorders also occur in the syndrome (Coventry, 1961), and

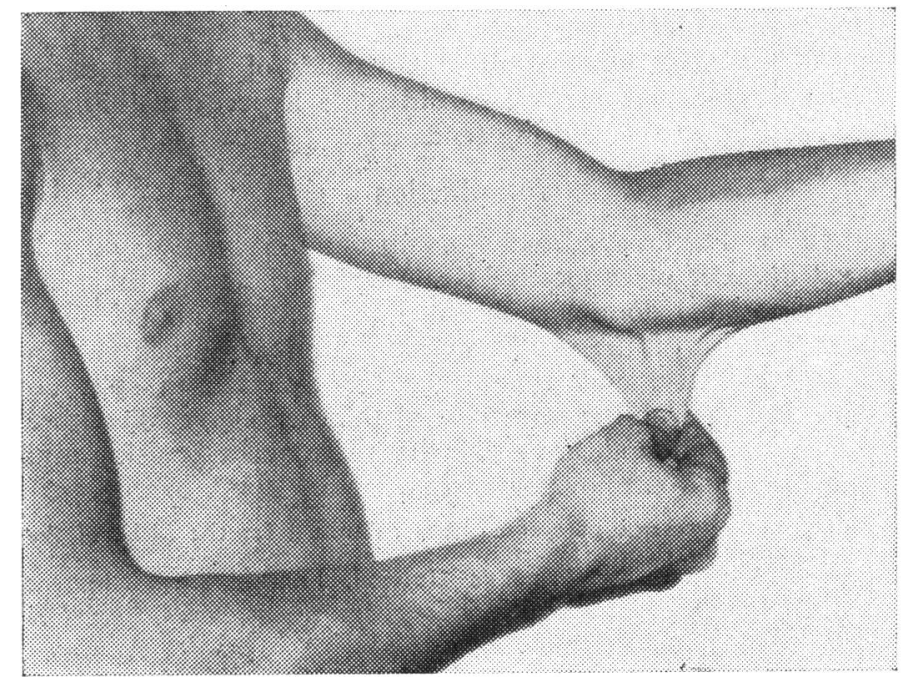

FIG. 3.-Hyperextensibility of the skin in Case 2.

Case 6 had postural kyphosis in childhood. Epicanthic folds are seen commonly in the Ehlers-Danlos syndrome (Johnson and Falls, 1949), and they were present in Cases 1 and 3. They were not present in any of the unaffected members of the family. Prematurity (Mories, 1954), vascular incidents (McFarland and Fuller, 1964), and cardiac lesions (Sestak, 1962) have also been reported in the Ehlers-Danlos syndrome. None of these features were present in any members of these families, but squint and pes planus were observed. In brief, the clinical features of the X-linked variety of the Ehlers-

Clinical Features of X-linked Ehlers-Danlos Syndrome

\begin{tabular}{|c|c|c|c|c|c|c|c|c|c|c|c|}
\hline No. & Case & Age & $\underset{\text { Hyperextensibility }}{\text { Skin }}$ & $\begin{array}{c}\text { Joint Hyper- } \\
\text { mobility }\end{array}$ & Scarring & Bruising & $\begin{array}{l}\text { Haemato- } \\
\text { mata }\end{array}$ & Dislocations & Effusions & $\begin{array}{c}\text { Pes } \\
\text { Planus }\end{array}$ & $\begin{array}{c}\text { Other } \\
\text { Features }\end{array}$ \\
\hline $\begin{array}{l}1 \\
2 \\
3 \\
4 \\
5 \\
6\end{array}$ & $\begin{array}{l}53 \text { IV } 1 \\
53 \text { IV } 2 \\
53 \text { IV } 4 \\
53 \text { II } 6 \\
53 \text { III } 7 \\
53 \text { IV } 8\end{array}$ & $\begin{array}{l}19 \\
18 \\
11 \\
55 \\
26 \\
13\end{array}$ & $\begin{array}{l}++t \\
++t \\
++t \\
++ \\
++ \\
+\end{array}$ & $\begin{array}{l}\text { Digits only } \\
\text { Digits only } \\
- \\
\text { Digits only }\end{array}$ & $\begin{array}{l}+ \\
+ \\
+ \\
+ \\
+\end{array}$ & $\begin{array}{l}+ \\
+ \\
\pm \\
-\end{array}$ & $\begin{array}{l}\bar{z} \\
\bar{z} \\
\bar{z}\end{array}$ & $\begin{array}{l}\bar{z} \\
\bar{z}\end{array}$ & $\begin{array}{c}+t+ \\
+t \\
+t \\
=\end{array}$ & $\begin{array}{l}+ \pm+ \\
+ \pm+ \\
=\end{array}$ & $\begin{array}{l}\text { Epicanthus } \\
\text { Recurrent squint } \\
\text { Epicanthus } \\
\text { Kyphosis during } \\
\text { childhood }\end{array}$ \\
\hline 7 & 54 III 1 & 36 & $+t+$ & Digits only & + & +++ & +++ & + & + & - & $\begin{array}{l}\text { Thoracic } \\
\text { asymmetry }\end{array}$ \\
\hline 8 & 54 III 2 & 22 & +++ & Digits only & - & +++ & +++ & ++++ & + & + & \\
\hline
\end{tabular}


Danlos syndrome appear to be marked hyperextensibility of the skin, with a minor or minimal tendency to skin-splitting. Joint hypermobility, if present, is limited to the digits, but orthopaedic sequelae may occur. A bruising tendency occurs and may be severe, as in Cases 7 and 8 .

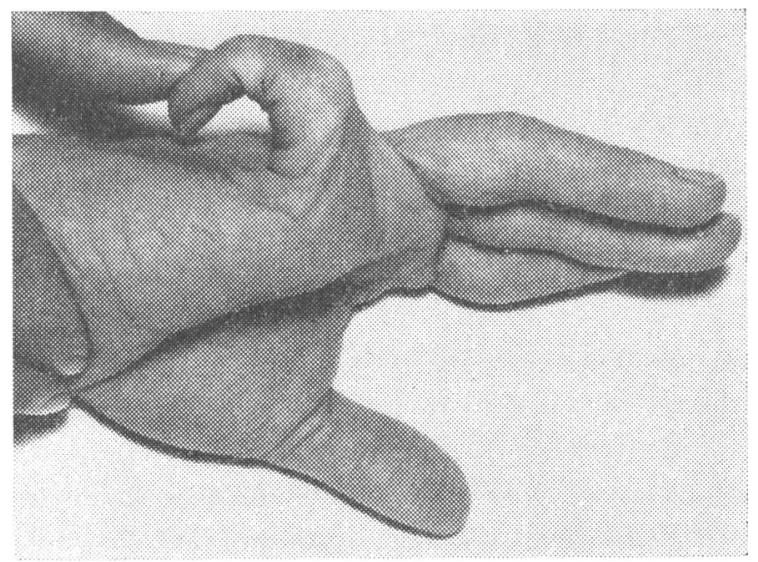

Fig. 4.-Joint hypermobility in Case 8.

\section{Linkage Investigations}

Sixteen members of the first family were avilable for $\mathrm{Xg}$ grouping, and two of them gave useful linkage information: IV 5 is a recombinant and IV 8 is a non-recombinant. III 4 has received the Ehlers-Danlos allele from her mother, II 2 , with $X g$ (the negative $\mathrm{Xg}$ gene), and handed it on to her son, IV 8, again with $X g$, so he is a non-recombinant. On the other hand, III 4 has handed on her "not Ehlers-Danlos" allele to her son IV 5 with her $X g$, so he is a recombinant. In addition, the descendants of II 2 show that crossing-over between the loci for Ehlers-Danlos syndrome and Xg must have occurred on at least one further occasion.

This finding of one recombinant and one non-recombinant in the first family to be grouped is enough to show that the loci for the Ehlers-Danlos syndrome and for the Xg groups are at least not very close to each other on the $\mathrm{X}$ chromosome. However, only more families can show whether the two loci are within measurable distance of each other.

All members of this family were tested for colour-blindness with Ischiara plates, but the only abnormality detected was a mild deutan type of colour-blindness in III 7. This finding suggests that the locus for the Ehlers-Danlos syndrome cannot be very close to that for deutan, for though II 2 has given the Ehlers-Danlos syndrome and deutan to her son, III 7, none of the other affected members of the family are colour-blind.

I am grateful to Dr. R. R. Race and Dr. R. Sanger, of the M.R.C. Blood Group Research Unit, the Lister Institute, for carrying out the $\mathrm{Xg}$ groupings, and for their kind assistance in the preparation of this paper.

This investigation was supported by grants from the Arthritis and Rheumatism Council and from the St. Thomas's Hospital Endowment Fund.

\section{REFERENCES}

Barabas, A. P. (1967). Brit. med. f., 2, 612.

Coventry, M. B. (1961). 7. Bone ft Surg., 43A, 855

Johnson, S. A. M., and Falls, H. F. (1949). Arch. Derm. Syph. (Chic.), 60,82 .

McFarland, W., and Fuller, D. E. (1964). New Engl. F. Med., 271, 1309. McKusick, V. A. (1964). On the X Chromosome of Man. Washington. McKusick, V. A. (1966a). Mendelian Inheritance in Man, p. 43. London. McKusick, V. A. (1966a). Mendelian Inheritance in Man, p. 43. London. McKusick, V. A. (1966b).

Mories, A. (1954). An Investigation into the Ehlers-Danlos Syndrome. M.D. Thesis, University of Edinburgh.

Ronchese, F. (1936). Amer. F. Dis. Child., 51, 1403.

Sestak, Z. (1962). Ann. hum. Genet., 25, 313.

\section{Medical Memoranda}

\section{Jaundice in Infectious Mononucleosis}

Brit. med. F., 1968, 3, 411-412

Jaundice is a well-recognized complication of infectious mononucleosis. Most cases with this complication show evidence of liver cell necrosis. Below we describe the case of a young man who presented with jaundice and in whom investigations confirmed a diagnosis of infectious mononucleosis. However, it was shown that the jaundice was mainly due to cold agglutinins with active haemolysis, while the liver cell necrosis played a minor part.

\section{CASE RePORT}

A man aged 20, a previously healthy student of physiology, was admitted to the Royal United Hospital, Bath, because of general malaise and increasing jaundice of four days' duration. He gave no history of contact with infectious mononucleosis or any viral infections either in the course of his social life or connected with his studies.

On admission his temperature was $100^{\circ} \mathrm{F} .\left(37.8^{\circ} \mathrm{C}.\right)$. There was slight icterus of his sclera but not elsewhere. Generalized lymphadenopathy was found; his liver was tender and palpable $1 \mathrm{~cm}$. below the right costal margin. Splenomegaly was not found at the time of admission but developed later. There were no abnormalities in his central nervous or cardiovascular system.
Laboratory findings on admission were as follows: haemoglobin 11.5 g./100 ml.; white cell count $15,000 / \mathrm{cu}$. mm., with $51 \%$ atypical mononuclear cells; E.S.R. $26 \mathrm{~mm}$. in one hour (Westergren). Examination of the peripheral blood film showed polychromasia, occasional spherocytes, and a $3 \%$ reticulocytosis.

An autoagglutinin at room temperature was noticed and cold agglutinins to a titre of $1: 256$ were found. The Paul-Bunnell test was positive to a titre of $1: 320$, was selectively absorbed by ox cells, and remained positive after absorption of the cold agglutinin. The presence of a specific antibody anti-i was confirmed by the National Blood Transfusion Service, Bristol.

Schumm's test was positive, and the haptoglobins were absent. Osmotic fragility was slightly increased, and haemolysis in the incubated fragility test occurred at $0.85 \% \mathrm{NaCl}$. The Coomb and Donath-Landsteiner tests were negative. Total serum bilirubin was $6.0 \mathrm{mg} . / 100 \mathrm{ml}$. The urine contained no haemoglobin pigments or haemosiderin, but urobilinogen was present in increased amounts.

Eight days after admission his haemoglobin had fallen to $9.5 \mathrm{~g} . /$ $100 \mathrm{ml}$. and the reticulocytosis rose to $6 \%$. Though the leucocytosis persisted the percentage of atypical cells fell, with a concurrent return to normality of the E.S.R. The bilirubin gradually fell to normal values, but his serum alanine aminotransferase rose to a maximum of $150 \mathrm{Karmen}$ units $/ \mathrm{ml}$. three days after admission, and then returned to normal during the following week.

For the first 12 days of his stay in hospital he felt generally unwell and complained of a sore throat, for which he received symptomatic treatment. During this time he continued to run a variable pyrexia with temperature spikes up to $100.6^{\circ} \mathrm{F}$. $\left(38.1^{\circ} \mathrm{C}\right.$.). Though his spleen was not palpable on admission it was easily 